\title{
Nutritional value of selected macroalgae
}

\author{
Rita Ferreira Patarra • Lisete Paiva • Ana Isabel Neto • \\ Elisabete Lima • José Baptista
}

Received: 5 February 2010 /Revised and accepted: 17 June 2010/Published online: 6 July 2010

(C) Springer Science+Business Media B.V. 2010

\begin{abstract}
Macroalgae are traditionally used in human and animal nutrition. Their protein and fiber content have been widely studied and differ according to the species, their geographic origin and their seasonal conditions. In addition to their value for human nutrition, seaweeds have multiple therapeutically applications (e.g., weight control, hypocholesterolemic, antioxidant and antitumor activities, others) and, in general, contribute and promote human health. In the archipelago of the Azores, the consumption of seaweeds is widespread and accepted as a common practice in some islands. This work is aimed at providing information on the protein and fiber content of the locally consumed species, to promote this regional food product that can be potentially profitable from the biotechnology and commercial perspective, and also benefit public health, particularly,
\end{abstract}

R. F. Patarra $(\bowtie) \cdot$ A. I. Neto

Grupo Biologia Marinha, Departamento Biologia, Universidade dos Açores,

Apartado 1422,

9501-801 Ponta Delgada, S. Miguel, Açores, Portugal

e-mail: rpatarra@uac.pt

R. F. Patarra $\cdot$ A. I. Neto $\cdot$ E. Lima $\cdot$ J. Baptista

Centro de Investigação de Recursos Naturais dos Açores (CIRN),

Departamento Biologia, Universidade dos Açores,

9501-801 Ponta Delgada, S. Miguel, Açores, Portugal

R. F. Patarra $\cdot$ A. I. Neto

Centro Interdisciplinar de Investigação Marinha e Ambiental

(CIIMAR),

Rua dos Bragas 289,

4050-123 Porto, Portugal

L. Paiva $\cdot$ E. Lima $\cdot$ J. Baptista

Departamento Ciências Tecnológicas e Desenvolvimento

(DCTD), Universidade dos Açores,

9501-855 Ponta Delgada, S. Miguel, Açores, Portugal taking into account the low level of marine pollution in the Azores archipelago. Protein and fiber content of eight seaweeds (Porphyra sp., Osmundea pinnatifida, Pterocladiella capillacea, Sphaerococcus coronopifolius, and Gelidium microdon, Rhodophyta; Cystoseira abies-marina and Fucus spiralis, Phaeophyta; Ulva compressa, Chlorophyta) were determined using the Kjeldahl method and the Weende method, respectively. The protein content ranged from 6.81 to 26.62 of dry weight for C. abies-marina and $U$. compressa, respectively. Fiber content was generally higher as compared with that in seaweeds from other origins and ranged from 33.82 to 63.88 for O. pinnatifida and $F$. spiralis, respectively.

Keywords Fiber $\cdot$ Protein $\cdot$ Seaweeds

\section{Introduction}

In recent years, the number of studies on macroalgae, their chemical composition, physiological and technological properties has grown exponentially, and these organisms have become a focus of commercial interest as potential ingredients of the so-called functional or health-promoting foods, as the use of macroalgae has grown exponentially during the last decade (Sekmokiene et al. 2007). When combined with its texture properties, the use of algae as a functional nutrient seems worthy for exploration (MacArtain et al. 2007). Presently, seaweed-based food additives are commonly used in the preparation of fast food. In this context, virtually every one eats some processed seaweeds every day (Dhargalkar and Verlecar 2009). Edible macroalgae are rich in resistant protein and dietary fiber (Mamatha et al. 2007). Protein content differs according to species being generally low in brown 
seaweeds $(3 \pm 15 \%$ of the dry weight $)$ as compared with green or red ones $(10 \pm 47 \%$ of the dry weight; Fleurence 1999).

Like vegetables, such as cabbage, wheat bran and sugar beet pulp (Burtin 2003), average, macroalgae may provide up to $12.5 \%$ of a person's daily fiber needs in an $8 \mathrm{~g}$ serving intake (MacArtain et al. 2007). The consumption of dietary fibers and plant cell walls containing such fiber components protects human organisms against a number of chronic diseases (e.g., colon cancer, Guidel-Urbano and Goni 2002). Soluble fibers ingestion may exert prebiotic effects probably due to the growth of bifidobacterium (Hoebler et al. 2000). In combination with high-glycemicintake foods, soluble fibers reduces the overall glycemic response (Goni et al. 2000), namely the reduction of blood cholesterol, and the modulation of blood glucose (Brennan 2005).

Traditionally, the Azoreans have gathered seaweeds either to eat or for chemically material extraction. The brown seaweed Fucus spiralis is a local delicacy; the swollen reproductive parts of the frond (the receptacles) are picked and eaten fresh. The red seaweed Porphyra sp. is collected, then fried or incorporated into soups or omelets. The red seaweeds Laurencia and Osmundea are pickled in vinegar with onions, and eaten with fried fish. The commercial harvesting of Pterocladiella capilacea and Gelidium microdon is a small-scale family business. The algae are gathered, dried, and then exported for agar extraction (Neto et al. 2005; personal observations).

With the current trend for consumers to embrace organically grown natural foods from clean environments, seaweeds should receive an increasing acceptance from the public. There is currently no legislation in Portugal regarding the use of specific seaweed as food products and in the Archipelago of the Azores coastal water bodies are in excellent environmental conditions, according to the parameters of the Water Frame Directive (Neto et al. 2009). Attending to this, in the present investigation we evaluate the protein and fiber contents of selected seaweeds common at the Azorean shores that may be potentially profitable from the biotechnology and commercial perspectives.

\section{Materials and methods}

Algae sampling and preparation

The studied Azorean seaweeds (Ulva compressa Linnaeus from Clorophyta; Cystoseira abies-marina (S.G. Gmelin) C. Agardh and Fucus spiralis Linnaeus, from Phaeophyta; Osmundea pinnatifida (Hudson) Stackhouse, Porphyra sp. C. Agardh, Pterocladiella capillacea (S.G. Gmelin)
Santelices \& Hommersand, Gelidium microdon Kützing and Sphaerococcus coronopifolius Stackhouse, from Rhodophyta) were collected in the littoral zone $\left(37^{\circ} 40^{\prime} \mathrm{N}\right.$ and $\left.25^{\circ} 31^{\prime} \mathrm{W}\right)$ of São Miguel Island (Azores, Portugal), during January and February of 2007. In the laboratory, algae were washed in distillate water, air-dried, kept in an air-tight container and frozen to $-20^{\circ} \mathrm{C}$ until further analyses. Previous to analytical procedures, seaweeds were defrosted and dried during $48 \mathrm{~h}$ at $65^{\circ} \mathrm{C}$ until constant weight and then homogenized with liquid nitrogen (ULTRA-TURRAX T50), re-dried at $60^{\circ} \mathrm{C}$ and stored in a desiccator.

\section{Determination of crude protein}

The organic nitrogen content of the dried macroalgae was quantified using a modified Kjeldahl procedure (AOAC 1990) in a VELP Scientifica UDK 132 apparatus. The digestion was performed with sulfuric acid $\left(\mathrm{H}_{2} \mathrm{SO}_{4}\right)$, $96 \%$, for $75 \mathrm{~min}$ at $420^{\circ} \mathrm{C}$, plus $75 \mathrm{~min}$ at $370^{\circ} \mathrm{C}$, then distilled with acid boric solution (2\%) and titrated with $\mathrm{HCl} 0.1 \mathrm{M}$. Estimation of the crude protein content was calculated multiplying the organic nitrogen by a factor of 6.25 .

\section{Determination of crude fiber}

The fiber determination of the dried macroalgae was performed using a modified Weende procedure (AOAC 1990) in a VELP Scientifica Dosi-Fiber apparatus. Acid hydrolysis was done with sulfuric acid $\left(\mathrm{H}_{2} \mathrm{SO}_{4}\right) 0.128 \mathrm{M}$ and the basic hydrolysis with potassium hydroxide $(\mathrm{KOH})$ $0.223 \mathrm{M}$. The cold extraction was performed with acetone; the sample was then dried $\left(1 \mathrm{~h}\right.$ at $\left.105^{\circ} \mathrm{C}\right)$ until reach a constant weight, cooled in a desiccator, weighted $\left(W_{1}\right)$, dried back in a muffle at $550^{\circ} \mathrm{C}$ for $3 \mathrm{~h}$ and reweighted $\left(W_{2}\right)$ after cooling in a desiccator. The crude fiber percentage was calculated following the equation: \%crude fiber $=100 \times$ $\left(W_{1}-W_{2} / W_{0}\right)$ (initial weight $1-1.5 \mathrm{~g}$ ).

\section{Results}

The yield of samples moisture varied between $9.75 \%$ for $O$. pinnatifida and $28.59 \%$ for G. microdon (Table 1).

The crude protein content varied within the studied species (Table 2), being the highest in $U$. compressa (26.62\%) followed by Porphyra sp. (25.80\%). The lowest protein values were found in the brown species $C$. abiesmarina $(6.81 \%)$ and F. spiralis $(10.77 \%)$.

The crude fiber content was high in all species (Table 2). It was higher in F. spiralis $(63.88 \%)$ followed by $G$. 
Table 1 Wet and dry weight of samples given in gram $(\mathrm{g})$ and yield given in percentage $(\%)$

\begin{tabular}{lccc}
\hline Species & $\begin{array}{l}\text { Wet weight } \\
(\mathrm{g})\end{array}$ & $\begin{array}{l}\text { Dry weight } \\
(\mathrm{g})\end{array}$ & $\begin{array}{l}\text { Yield } \\
(\%)\end{array}$ \\
\hline Rhodophyta & & & \\
Sphaerococcus coronopifolius & 143.67 & 20.24 & 14.09 \\
Gelidium microdon & 301.74 & 86.26 & 28.59 \\
Pterocladiella capillacea & 106.70 & 27.26 & 25.55 \\
Porphyra sp. & 156.00 & 31.30 & 20.06 \\
Osmundea pinnatifida & 101.72 & 9.92 & 9.75 \\
Phaeophyta & & & \\
Cystoseira abies-marina & 121.94 & 19.75 & 16.20 \\
Fucus spiralis & 106.50 & 19.22 & 18.05 \\
Chlorophyta & & & \\
Ulva compressa & 111.50 & 18.90 & 16.95 \\
\hline
\end{tabular}

microdon (57.37\%), C. abies-marina (56.34\%), P. capillacea $(52.08 \%)$ and lower in O. pinnatifida $(33.82 \%)$.

\section{Discussion}

In general, the crude protein content recorded for the studied red and brown seaweeds was similar to the one reported in other studies (e.g., Fleurence 1999; Rupérez and Saura-Calixto 2001; Burtin 2003; McDermid and Stuercke 2003; Barbarino and Lourenço 2005; Marinho-Soriano et al. 2006; Dawczynski et al. 2007; Hwang et al. 2007; Marsham et al. 2007; Chakraborty and Santra 2008; Polat and Ozogul 2008). On the other hand, the crude protein content obtained for $U$. compressa $(26.62 \%$, Table 2$)$ in the present study is higher than the one published for the genus by other authors (3-14\%, see Dere et al. 2003; McDermid and Stuercke 2003; Aguilera-Morales et al. 2005; Renaud and Luong-Van 2006; Chakraborty and Santra 2008). These results may reflect the influence of geographic origin, climate, and season and are also likely to be related to environmental differences or different sampling methodologies. In fact, protein content of seaweed varies greatly and could be influenced by season and environmental conditions (Fleurence 1999; Dawczynski et al. 2007). GallandIrmouli et al. (1999) working with Palmaria palmata (Linnaeus) Kuntze registered higher protein levels in plants collected during the end of the winter period and spring and lower amounts in the ones sampled during the summer months.

In general, all the studied species presented high crude fiber content (Table 2), in agreement with other studies (Wong and Cheung 2000; Rupérez and Saura-Calixto 2001; McDermid et al. 2005). From all species, F. spiralis had the highest crude fiber content (63.88\%), even higher than the value reported by Rupérez and Saura-Calixto (2001) for other species of the genus (F. vesiculosus Linnaeus, $50.09 \pm 1.77 \%$ ). This fact may be related to the species, geographical location, season, and/or temperature (Dawes 1998; Jiménez-Escrig and Combrodón 1999). It is also known that the drying method could affect the nutritional value of seaweeds (Chan et al. 1997). If properly dried, seaweed samples can be stored for a number of years without appreciable loss of their gel content (FAO 1976).

\section{Conclusion}

This is the first study investigating the nutritional composition of seaweeds usually consumed in the Azores Islands. It revealed important results in what concerns protein and fiber content. The level of digestibility of proteins seems to be related to the amount of soluble fiber in the algae, preventing bioavailability of the proteins (MacArtain et al. 2007). Further work involving biotechnological treatment of the studied seaweeds by enzymatic degradation of algal fibers could improve protein digestibility and, therefore, will increase their nutritional value.

Table 2 Crude protein and crude fiber proximate composition given in mean relative $\%$, (average of $n=2$ )

\begin{tabular}{|c|c|c|c|c|}
\hline Species & $\begin{array}{l}\text { Crude } \\
\text { protein }\end{array}$ & $\begin{array}{l}\text { Mean } \\
\text { value }\end{array}$ & $\begin{array}{l}\text { Crude } \\
\text { fiber }\end{array}$ & $\begin{array}{l}\text { Mean } \\
\text { value }\end{array}$ \\
\hline \multicolumn{5}{|l|}{ Rhodophyta } \\
\hline \multirow[t]{2}{*}{ Gelidium microdon } & 14.61 & 15.18 & 56.71 & 57.37 \\
\hline & 15.75 & & 58.02 & \\
\hline \multirow[t]{2}{*}{ Osmundea pinnatifida } & 20.32 & 20.64 & 33.94 & 33.82 \\
\hline & 20.97 & & 33.69 & \\
\hline \multirow[t]{2}{*}{ Porphyra sp. } & 25.64 & 25.80 & 43.09 & 40.98 \\
\hline & 25.97 & & 38.86 & \\
\hline \multirow[t]{2}{*}{ Pterocladiella capillacea } & 20.56 & 20.52 & 52.96 & 52.08 \\
\hline & 20.48 & & 51.19 & \\
\hline \multirow[t]{2}{*}{ Sphaerococcus coronopifolius } & 19.60 & 19.56 & 40.60 & 41.25 \\
\hline & 19.51 & & 41.91 & \\
\hline \multicolumn{5}{|l|}{ Phaeophyta } \\
\hline \multirow[t]{2}{*}{ Cystoseira abies-marina } & 6.94 & 6.81 & 56.26 & 56.34 \\
\hline & 6.69 & & 56.40 & \\
\hline \multirow[t]{2}{*}{ Fucus spiralis } & 10.56 & 10.77 & 61.79 & 63.88 \\
\hline & 10.97 & & 65.97 & \\
\hline \multicolumn{5}{|l|}{ Chlorophyta } \\
\hline \multirow[t]{2}{*}{ Ulva compressa } & 27.52 & 26.62 & 40.24 & 41.16 \\
\hline & 25.72 & & 42.08 & \\
\hline
\end{tabular}


Acknowledgements The authors wish to thank Catarina Santos, Francisco Wallenstein, Daniel Torrão, João Brum and Nuno Álvaro for help with the field work. The surveys performed in the present study comply with the current laws of Portugal.

\section{References}

Aguilera-Morales M, Casas-Valdeza M, Carrillo-Dominguez S, Gonzalez-Acosta B, Perez-Gilb F (2005) Chemical composition and microbiological assays of marine algae Enteromorpha spp. as a potential food source. J Food Compos Anal 18:79-88

AOAC (1990) Official methods of analysis of the Association of Official Analytical Chemists. 15th edition. Washington, DC, Association of Official Analytical Chemists

Barbarino E, Lourenço SO (2005) An evaluation of methods for extraction and quantification of protein from marine macro- and microalgae. J Appl Phycol 17:447-460

Brennan C (2005) Dietary fibre, glycaemic response, and diabetes. Mol Nutr Food Res 49:560-570

Burtin P (2003) Nutritional value of seaweeds. Electron J Environ Agric Food Chem 2:498-503

Chakraborty S, Santra SC (2008) Biochemical composition of eight benthic algae collected from Sunderban. Indian J Mar Sci 37:329-332

Chan JCC, Cheung PCK, Ang PO (1997) Comparative studies on the effect of three drying methods on the nutritional composition of seaweed Sargassum hemiphyllum (Turn) C Ag. J Agri Food Chem 45:3056-3059

Dawczynski C, Schubert R, Jahreis G (2007) Amino acids, fatty acids, and dietary fibre in edible seaweed products. Food Chem 103:891-899

Dawes CJ (1998) Marine botany. Wiley, New York, p 480

Dere S, Dalkıran N, Karacaoglu D, Yildiz G, Dere E (2003) The determination of total protein, total soluble carbohydrate and pigment contents of some macroalgae collected from GemlikKaracaali (Bursa) and Erdek-Ormanl (Balıkesir) in the Sea of Marmara, Turkey. Oceanolog 45:453-471

Dhargalkar VK, Verlecar XN (2009) Southern Ocean seaweeds: a resource for exploration in food and drugs. Aquaculture 287:229-242. doi:10.1016/j.aquaculture.2008.11.013

FAO (1976) Production, trade and utilization of seaweeds and seaweed products. In FAO Fisheries Technical Paper No.159; Food and Agriculture Organization of the United Nations: Rome, p 8. Retrieved from http://www.fao.org/docrep/005/ac860e/ ac $860 \mathrm{e} 00 . \mathrm{htm}$ on 8 January 2010

Fleurence J (1999) Seaweed proteins: biochemical, nutritional aspects and potential uses. Trends Food Sci Technol 10:25-28

Galland-Irmouli AV, Fleurence J, Lamghari R, LucËon M, Rouxel C, Barbaroux O, Bronowicki JP, Vuillaume C, Guéant JL (1999) Nutritional value of proteins from edible seaweed Palmaria palmate (dulse). J Nutr Biochem 10:353-359

Goni I, Valdivieso L, Garcia-Alonso A (2000) Nori seaweed consumption modifies glycemic response in healthy volunteers. Nutr Res 20:1367-1375
Guidel-Urbano M, Goni I (2002) Effect of edible seaweeds (Undaria pinnitafida and Porphyra tenera) on the metabolic activities of intestinal microflora in rats. Nutr Res 22:323-331

Hoebler C, Guillon F, Darcy-Vrillon B, Vaugelade P, Lahaye M, Worthington E, Dué P-H, Barry J-L (2000) Supplementation of pig diet with algal fibre changes the chemical and physicochemical characteristics of digesta. J Sci Food Agric 80:1357-1364

Hwang EK, Amano H, Park CS (2007) Assessment of the nutritional value of Capsosiphon fulvescens (Chlorophyta): developing a new species of marine macroalgae for cultivation in Korea. $\mathrm{J}$ Appl Phycol 19:787-793

Jiménez-Escrig A, Cambrondón IG (1999) Evaluación nutricional y efectos fisiológicos de macroalgas marinas comestibles. Archivos LatinoAmericos de Nutricion 49(2):114-120

MacArtain P, Christopher RG, Brooks M, Campbell R, Rowland IR (2007) Nutritional value of edible seaweeds. Nutr Rev 65:535543

Mamatha BS, Namitha KK, Senthil A, Ravishankar GA (2007) Studies on use of Enteromorpha in snack food. Food Chem 101:1707-1713

Marinho-Soriano E, Fonseca PC, Carneiro MAA, Moreira WSC (2006) Seasonal variation in the chemical composition of two tropical seaweeds. Bioresour Technol 97:2402-2406

Marsham S, Scott GW, Tobin ML (2007) Comparison of nutritive chemistry of a range of temperate seaweeds. Food Chem 100:1331-1336

McDermid KJ, Stuercke B (2003) Nutritional composition of edible Hawaiian seaweeds. J Appl Phycol 15:513-524

McDermid KJ, Stuercke B, Haleakala OJ (2005) Total dietary fiber content in Hawaiian marine algae. Bot Mar 48:437-440

Neto AI, Tittley I, Raposeiro PM (2005) Flora Marinha do Litoral dos Açores. Secretaria Regional do Ambiente e do Mar, $148 \mathrm{pp}$

Neto AI, Brotas V, Azevedo JMN, Patarra RF, Álvaro NMV, Gameiro C, Prestes ACL, Nogueira EM (2009) Qualidade de águas costeiras do Grupo Oriental do arquipélago dos Açores e proposta de monitorização. Departamento de Biologia, Universidade dos Açores. iii+70 pp.+Anexos

Polat S, Ozogul Y (2008) Biochemical composition of some red and brown macro algae from the Northeastern Mediterranean Sea. Int J Food Sci Nutr 59:566-572

Renaud SM, Luong-Van JT (2006) Seasonal variation in the chemical composition of tropical Australian marine macroalgae. J Appl Phycol 18:381-387

Rupérez P, Saura-Calixto F (2001) Dietary fibre and physicochemical properties of edible Spanish seaweeds. Eur Food Res Technol 212:349-354

Sekmokienė D, Liutkevičius A, Malakauskas M (2007) Functional food and it's ingredients. Vet Zoot 37:72-78

Wong KH, Cheung PCK (2000) Nutritional evaluation of some subtropical red and green seaweeds Part I-proximate composition, amino acid profiles and some physico-chemical properties. Food Chem 71:475-482 